\title{
Can the C-reactive protein-to-plasma albumin ratio be an alternative scoring to show mortality and morbidity in patients with colorectal cancer?
}

\author{
(1) Yeliz Şahiner, M.D., ${ }^{1}$ () Murat Baki Yıldırım, M.D. ${ }^{2}$
}

\author{
${ }^{1}$ Department of Anesthesiology and Reanimation, Hitit University Faculty of Medicine, Çorum-Turkey \\ ${ }^{2}$ Department of General Surgery, Hitit University Faculty of Medicine, Çorum-Turkey
}

\begin{abstract}
BACKGROUND: This study aims to demonstrate the sensitivity and specificity of C-reactive protein to plasma albumin (CRP/ALB) ratio in predicting morbidity and mortality in patients operated for colorectal cancer followed up in the intensive care unit by comparing it with current scoring systems.

METHODS: The data of patients who underwent surgery for colorectal cancer and hospitalized in the intensive care unit between 2015-2018 with available data were retrospectively analyzed in this study. The CRP/ALB ratio, the physiological and operative severity score for the enumeration of mortality and morbidity (POSSUM) prepared for both gastrointestinal and colorectal surgery, and the Association of Coloproctology of Great Britain and Ireland (ACPGBI-CRC) scoring system prepared for colorectal patients, were compared to determine their success in predicting mortality and morbidity.
\end{abstract}

RESULTS: A total of I 19 patients were included in this study. Mortality was observed in nine patients and morbidity was observed in 38 patients. When compared with P-POSSUM, which is the only scoring system showing morbidity, the CRP/ALB ratio was found to have a high prediction accuracy. The $C$ reactive protein to plasma albumin ratio values was found to have lower power than $\mathrm{P}-\mathrm{PO} O S S \mathrm{M}$, CR-POSSUM and ACPGBI-CRC.

CONCLUSION: Although scoring systems are useful in predicting morbidity and mortality in colorectal patients, they are difficult to use in practice since they include many parameters. that the findings obtained in this study suggest that the CRP/ALB ratio, which can be calculated without any additional cost, may help the clinician predict mortality and especially morbidity.

Keywords: Aged; colorectal cancer; intensive care units; organ dysfunction scores; prognosis; ROC curve.

\section{INTRODUCTION}

Malignancy patients are of vital importance in general surgery practice. The vast majority of malignancy patients is of advanced age and naturally has many comorbid diseases. Preoperative and postoperative mortality and morbidity rates of individuals in the advanced age group are higher than that of the younger age group. Before scheduling a major surgical intervention, it is important to know the perioperative morbidity or mortality of patients concerning taking measures against complications that may develop. Various scoring systems are used to predict morbidity and mortality of such high-risk patients before surgery or during intensive care follow-ups after surgery. The common characteristic of these scoring systems is to predict potential mortality and morbidity by calculating the various measurement and laboratory values of the patient within a certain scale and to draw the attention of the clinician. Otherwise, they do not have any therapeutic property.

The group of patients with colorectal malignancy is also in the risk group for morbidity and mortality because of both age and diseases. Due to the complications that may develop in

Cite this article as: Şahiner Y, Yıldırım MB. Can the C-reactive protein-to-plasma albumin ratio be an alternative scoring to show mortality and morbidity in patients with colorectal cancer?. Ulus Travma Acil Cerrahi Derg 2020;26:580-585.

Address for correspondence: Yeliz Şahiner, M.D.

Hitit Üniversitesi Tıp Fakültesi, Anesteziyoloji ve Reanimasyon Anabilim Dalı, Çorum, Turkey

Tel: +90364 - 2193000 E-mail: yelizsahiner@gmail.com

Ulus Travma Acil Cerrahi Derg 2020;26(4):580-585 DOI: 10.14744/tjtes.2020.344I2 Submitted: 17.02.2020 Accepted: 08.05.2020 Online: I5.06.2020

Copyright 2020 Turkish Association of Trauma and Emergency Surgery 
the follow-up and treatment of such patients, their lengths of hospital stay are prolonged, additional care and intervention costs are required, and the initiation of patients on treatments such as chemotherapy is delayed. ${ }^{[l]}$ One of the commonly used scoring systems to predict morbidity and mortality of such risky patients is the physiological and operative severity score for the enumeration of mortality and morbidity (POSSUM) ${ }^{[2]}$ POSSUM is a very comprehensive scaling system consisting of twelve physiological and six operative parameters. ${ }^{[3]}$ Although POSSUM makes it easy to predict mortality and morbidity, it is often difficult to calculate a total of 18 parameters in the daily routine. Therefore, various disease-specific modifications have been developed to facilitate calculations. Scoring modifications specific to diseases and surgical procedures to be performed, such as V-POSSUM for vascular surgical interventions, Cr-POSSUM for colon surgery, P-POSSUM for gastrointestinal surgery, have been made. ${ }^{[4,5]} \mathrm{Cr}$-POSSUM, customized for colorectal surgery patients, includes six physiological parameters and four operative parameters. Therefore, it is easier to calculate. ${ }^{[6]}$

Another scoring system published by the Association of Coloproctology of Great Britain in 2003 for use in colorectal surgery patients and updated in 2010 with a high accuracy rate is the Association of Coloproctology of Great Britain and Ireland (ACPGBI-CRC). ${ }^{[]]}$In this scoring system, five parameters, including the American Society of Anesthesiologists (ASA) risk assessment, are calculated. The small number of parameters to be analysed has naturally increased its clinical use.

Recently, it is popular to analyse the C-reactive protein (CRP) to plasma albumin (ALB) ratio, which has been argued to have a predictive value to predict morbidity and mortality in intensive care patients. ${ }^{[8]} \mathrm{CRP}$ is an acute-phase protein produced by stimulation of various cytokines in response to infection, ischemia, trauma and other inflammatory conditions. On the other hand, low serum albumin is known to be associated with poor prognosis and mortality. ${ }^{[9]}$ Both CRP and ALB are practical, inexpensive and easily accessible tests routinely used in ICU patients.

In this study, the sensitivity and specificity of the CRP/ALB ratio in predicting postoperative morbidity and mortality in patients undergoing colorectal surgery were investigated by comparing it with P-POSSUM, Cr-POSSUM, and ACPGBICRC scores.

\section{MATERIALS AND METHODS}

The data of patients who were admitted to the general surgery outpatient clinic of Hitit University Faculty of Medicine for colorectal malignancy, operated and followed up in the intensive care unit between January 2015 and November 2018 were retrospectively investigated from the archive and hospital computer database. Patients under the age of 18 years, patients who did consent their information to be used for this study, patients whose files could not be completely reached, and patients who underwent colorectal surgery but not admitted to the intensive care unit were excluded from this study.

The demographic data, ASA scores, biochemical values, comorbidities, vital signs, and operative information in the operative notes of the patients were collected. Recording the levels of C-reactive protein (CRP) and plasma albumin (ALB) taken in the first 24 hours postoperatively from the patient files, the CRP/ALB ratio of all patients was calculated. Using the infrastructure of the website http://www.riskprediction. org.uk, P-POSSUM, Cr-POSSUM and ACPGBI-CRC scores of all patients were calculated with the help of the data in the patient files. The parameters used to calculate all scores are given in Table I. The morbidity and mortality developed in the patients were noted. For the morbidity and mortality, the first 30 days after surgery were considered in the calculations.

\section{Institutional Review Board (IRB)}

This study was conducted according to Helsinki human declaration guides. Written informed consent is taken. Institutional Review Board approved this study (Hitit University, Erol Olçok Training and Research Hospital, Date: 31.01.2020, IRB Number: 40600303-000-944).

\section{Statistical Method}

The statistical analyses of the data obtained were carried out using SPSS v.22.0 (SPSS Inc., Chicago, IL, USA, Licensed to Hitit University). The frequency and mean values of the demographic data were calculated. The predictivity scores, CRP/ ALB ratio and postoperative morbidity and mortality rates were compared.

Whether CRP/ALB and P-POSSUM scores could be prognostic markers to compare morbidity and whether CRP/ALB, ACPGBI-CRC, P-POSSUM, CR-POSSUM scores could be prognostic markers to compare mortality were analyzed with Receiver Operating Characteristic (ROC) curve. The area under the ROC curve (AUC) was evaluated as 0.9-1: excellent, 0.8-0.9: good, 0.7-0.8: moderate, 0.6-0.7: weak, and 0.5-0.6: failed. The Youden index (maximum sensitivity and selectivity) was used to determine the optimal cut-off point after the ROC analysis. Sensitivity, selectivity, positive-negative predictive values, and likelihood ratio $(+)$ values were calculated by using cut-off points after the ROC analysis to determine the discriminatory power of the marker. The level of statistical significance was set to $p<0.05$.

\section{RESULTS}

The data of a total of 119 patients who met the study criteria were evaluated. Of the patients, $34.45 \%(n=4 I)$ were female, $65.55 \%(n=78)$ were male, and the mean age was 68 (years). Considering the surgical procedure performed, it was found that of the patients, $32.7 \%(n=39)$ underwent right hemi- 
Table I. Parameters of the scoring systems

\begin{tabular}{|c|c|c|c|}
\hline & P-possum & Cr-Possum & ACPGBI-CRC \\
\hline \multirow[t]{12}{*}{ Physiological parameters } & Age & Age & Age \\
\hline & Cardiac & Cardiac & ASA score \\
\hline & Respiratory & Systolic blood pressure & Cancer stage \\
\hline & ECG & Pulse & \\
\hline & Systolic blood pressure & Haemoglobin & \\
\hline & Pulse & Urea & \\
\hline & Haemoglobin & & \\
\hline & White blood cell & & \\
\hline & Urea & & \\
\hline & Sodium & & \\
\hline & Potassium & & \\
\hline & Glasgow Coma Score & & \\
\hline \multirow[t]{6}{*}{ Operative parameters } & Type of surgery & Type of surgery & Type of surgery \\
\hline & Number of procedures & Contamination & Urgency \\
\hline & Blood loss & Presence of malignancy & \\
\hline & Contamination & Urgency & \\
\hline & Presence of malignancy & & \\
\hline & Urgency & & \\
\hline
\end{tabular}

ACPGBI-CRC: Association of Coloproctology of Great Britain and Ireland; ECG: Electrocardiogram.

colectomy, $12.6 \%(n=15)$ underwent left hemicolectomy, $6.7 \%(n=8)$ underwent transverse colectomy, $32.7 \%(n=39)$ underwent anterior resection, $13.4 \%(n=16)$ underwent low anterior resection, and $0.8 \%(n=I)$ underwent total colectomy surgery. It was found that $31.9 \%(n=38)$ of the patients developed postoperative morbidity. In addition, mortality was observed in $7.5 \%(n=9)$ of the patients within 30 days

Table 2. ROC curve results, sensitivity, specificity, positivenegative predictive and likelihood ratio $(+)$ values for morbidity

\begin{tabular}{lcc}
\hline & CRPIALB & P-POSSUM \\
\hline AUC $(95 \% \mathrm{Cl})$ & $0.817(0.73 \mathrm{I}-0.904)$ & $0.734(0.635-0.833)$ \\
P-values & $<0.00 \mathrm{I}$ & $<0.00 \mathrm{I}$ \\
Cut-off & 6.675 & 44.25 \\
Sensitivity & $0.763(0.594-0.879)$ & $0.605(0.434-0.755)$ \\
Specificity & $0.790(0.682-0.869)$ & $0.814(0.710-0.889)$ \\
PPV & $0.630(0.475-0.764)$ & $0.605(0.434-0.755)$ \\
NPV & $0.877(0.774-0.938)$ & $0.814(0.710-0.889)$ \\
LR + & $3.64(2.30-5.75)$ & $3.26(\mathrm{I} .93-5.5 \mathrm{I})$ \\
\hline
\end{tabular}

ROC: Receiver Operating Characteristic; CRP/ALB: C-reactive protein to plasma albumin; POSSUM: Physiological and operative severity score for the enumeration of mortality and morbidity; AUC: Area under the curve; $\mathrm{Cl}$ : Confidence interval; PPV: Positive predictive value; NPV: Negative predictive value; LR: Likelihood ratio. postoperatively. The CRP/ALB ratio and P-Possum score were compared to predict morbidity. The cut-off value of the CRP/ALB ratio for morbidity was 6.6675 . Based on this cutoff value, it was found to predict morbidity with a sensitivity of 0.763 and a specificity of 0.790 . These values were 0.605 and 0.814 for P-Possum, respectively $(p<0.05)$. The AUC was 0.817 for CRPIALB, while the AUC was 0.734 for P-Possum (Table 2). In the prediction of the mortality, the cut-off value of the CRP/ALB ratio was determined as 13.66. The CRP/ ALB ratio predicted mortality with a sensitivity of 0.777 and a specificity of 7.790 , while these values were 0.888 and 0.900 for ACPGBI-CRC, 0.777 and 0.763 for P-POSSUM, 0.888 and 0.700 for CR-POSSUM, respectively $(p<0.05)$. The AUC was 0.789 for CRPIALB, 0.919 for ACPGBI-CRC, 0.795 for PPOSSUM and 0.838 for CR-POSSUM (Table 3).

\section{DISCUSSION}

The surgical procedures performed for colorectal malignancies are of great importance in current practice. Since most of the patients are in the geriatric age group, morbidity and mortality are often seen in the postoperative follow-up period. ${ }^{[10]}$ In this study, the mean age of the patients was 68 years. In this study, not all subjects underwent elective operations. There were eight patients that were classified as "urgent". Among these patients, six patients underwent sigmoid resection, one hemicolectomy, and one transverse colectomy. Of the 26 patients that were classified as "emergency", five underwent right hemicolectomy, one transverse 
Table 3. ROC curve results, sensitivity, specificity, positive-negative predictive and likelihood ratio $(+)$ values for mortality

\begin{tabular}{lcccc}
\hline & CRPIALB & ACPGBI-CRC & P-POSSUM EX & CR-POSSUM \\
\hline AUC $(95 \% \mathrm{Cl})$ & $0.789(0.613-0.965)$ & $0.919(0.822-1.000)$ & $0.795(0.661-0.930)$ & $0.838(0.714-0.962)$ \\
P values & 0.004 & $<0.001$ & 0.003 & 0.001 \\
Cut-off & 13.66 & 0.0955 & 0.034 & 0.0435 \\
Sensitivity & $0.777(0.401-0.960)$ & $0.888(0.506-0.994)$ & $0.777(0.401-0.960)$ & $0.888(0.506-0.994)$ \\
Specificity & $0.790(0.700-0.860)$ & $0.900(0.824-0.946)$ & $0.763(0.671-0.837)$ & $0.700(0.604-0.781)$ \\
PPV & $0.233(0.106-0.427)$ & $0.421(0.211-0.660)$ & $0.212(0.096-0.393)$ & $0.195(0.093-0.353)$ \\
NPV & $0.977(0.913-0.996)$ & $0.990(0.937-0.999)$ & $0.976(0.910-0.995)$ & $0.987(0.920-0.999)$ \\
LR + & $3.71(2.24-6.15)$ & $8.88(4.84-16.29)$ & $3.29(2.02-5.34)$ & $2.96(2.05-4.27)$ \\
\hline
\end{tabular}

ROC: Receiver Operating Characteristic; CRP/ALB: C-reactive protein to plasma albumin; POSSUM: Physiological and operative severity score for the enumeration of mortality and morbidity; AUC: Area under the curve; Cl: Confidence interval; PPV: Positive predictive value; NPV: Negative predictive value; LR: Likelihood ratio.

hemicolectomy, four low anterior resection and 16 sigmoid resection. The differentiation of the surgical timing status of these patients would not have improved statistical significance. Hence, these patients were not divided into two separate groups. Also, whether the patients are classified as an emergency or elective does not affect the pattern or results of the study. If we are to elaborate on why it would not do so, the parameters used in the calculation of scoring systems already question whether the operation is elective, emergency, or urgent, and assigns a risk score accordingly. Therefore, the score will be lower if the operation is classified as elective and higher if classified as an emergency. Considering all these, it can be inferred that the "emergency" or "elective" status of the patients will not hinder the utility of CRP/albumin ratio in scoring systems in predicting morbidity and mortality.

High-risk patients presenting with postoperative morbidity increase the cost of care due to prolonged length of stay in intensive care, additional interventions and treatments. For this reason, although many scoring systems have been devel- oped to predict morbidity and mortality for ICU patients, the high number of and complex parameters used often prevent them from being used in practice. Therefore, Prytherch et al. ${ }^{\left[{ }^{\prime \prime}\right]}$ developed a scoring system in 1998 to predict morbidity and mortality in surgical patients. Although P-POSSUM predicts mortality for surgical patients with high accuracy, Tekkis et al., ${ }^{[5]}$ who needed a scoring system specific to colorectal patients, developed the CR-POSSUM scoring system. CR-Possum consists of six physiological and four operative parameters and predicts postoperative mortality with high accuracy. Since the scoring systems include many parameters that are not specific to patients with colorectal cancer, a 5-parameter ACPGBI-CRC scoring system, including the patient's age, ASA score, stage of colorectal cancer, whether the surgery is urgent and the type of surgery planned to be performed has been developed. ${ }^{[2]}$

Recent studies have shown that the CRP/ALB ratio is very reliable in predicting 30-day mortality in patients followed up in the intensive care unit. ${ }^{[13]}$ Moreover, the CRP/ALB ratio

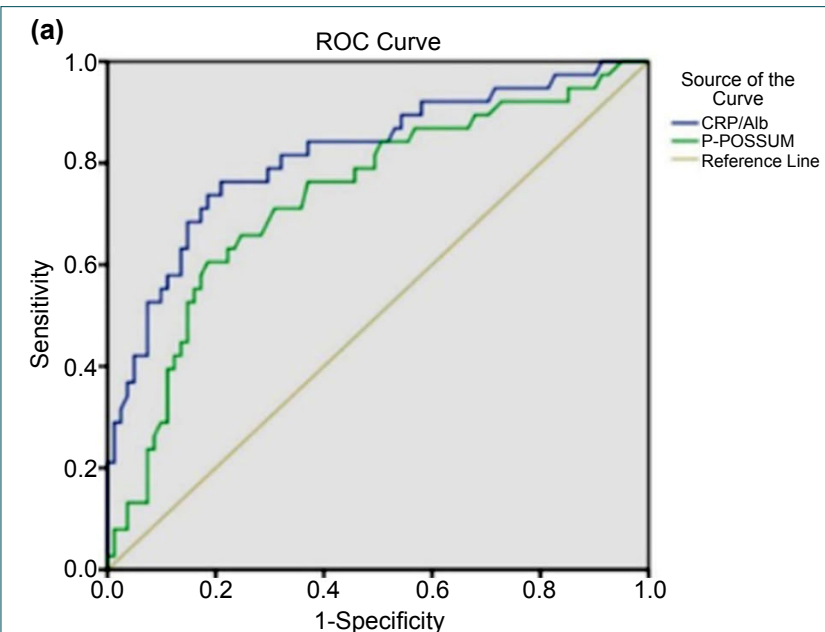

Diagonal segments are produced by ties

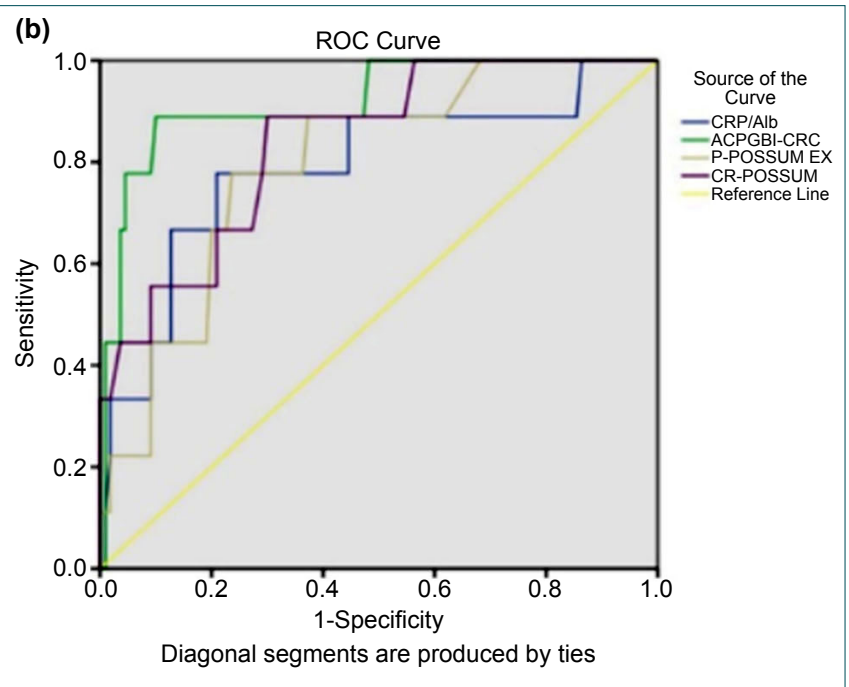

Figure 1. Sensitivity and specificity rates. (a) ROC curve of CRP/ALB and P-POSSUM. (b) ROC curve of all scoring systems on mortality. 
has been used to predict prognosis in patients with colorectal cancer. ${ }^{[14]}$ We analyzed the postoperative 12th hour's blood samples for calculating the CRP/ALB ratio. In the intensive care practice of our institution, for all patients, samples are retrieved for the required culture exams at the time of admission to the intensive care unit and routine blood samples are retrieved 12 hours after admission. Since our study was retrospective in nature, we were able to access the $12^{\text {th }}$-hour blood test results of our subjects. In other words, we were not able to access the $24^{\text {th }}$ - or $48^{\text {th }}$-hour blood test results. Therefore, there was no specific reason for using postoperative $12^{\text {th }}$-hour blood test results other than that these results were available in patient files.

When P-POSSUM and the CRPIALB ratio that predicts morbidity in colorectal cancer patients were compared in this retrospective study, the AUC was calculated as 0.817 , considering the optimal cut-off value for CRPIALB ratio 6.675 . This result was found to be higher than the value of 0.734 calculated for P-POSSUM. P-POSSUM appears to be more valuable in predicting morbidity (Fig. I).

There are studies comparing these three scoring systems in predicting mortality. ACPBGI-CRC has been shown to be more valuable than CR-POSSUM and P-POSSUM. ${ }^{[15]}$ In this study, ACPBGI-CRC was also found to be the most reliable test for predicting mortality. When the cut-off value was taken as 13.66 for the CRPIALB ratio, the AUC was calculated as 0.789 (Fig. I). Although the specificity of CRP/ALB was higher than that of P-POSSUM and CR-POSSUM, its sensitivity was low. Since the number of mortality was nine in this study, the margin of error of one patient resulted in a statistically significant difference. The limited number of patients included in this study, the inclusion of only the patients admitted to the intensive care unit, and the retrospective nature of the study were among the limitations of this study. We are of the opinion that prospective observational studies to be conducted with a larger sample size may more explicitly demonstrate the power of these parameters in predicting morbidity and mortality.

\section{Conclusion}

Although scoring systems are useful in predicting morbidity and mortality in colorectal patients, they are difficult to use in practice since they include many parameters. The findings obtained in this study suggest that the CRP/ALB ratio, which can be calculated without any additional cost, may help the clinician predict mortality and especially morbidity.

\section{Acknowledgements}

Authors thank Dr. Emre Demir from the Department of Biostatistics for his help with statistical analysis.

Ethics Committee Approval: Approved by the local ethics committee.
Peer-review: Internally peer-reviewed.

Authorship Contributions: Concept: Y.Ş., M.B.Y.; Design: Y.Ş., M.B.Y.; Supervision: Y.Ş., M.B.Y.; Fundings: Y.Ş., M.B.Y.; Materials: Y.Ş., M.B.Y.; Data: Y.Ş.; Analysis: Y.Ş., M.B.Y.; Literature search: Y.Ş., M.B.Y.; Writing: Y.Ş., M.B.Y.; Critical revision: Y.Ş.

Conflict of Interest: None declared.

Financial Disclosure: The authors declared that this study has received no financial support.

\section{REFERENCES}

1. Hendren S, Birkmeyer JD, Yin H, Banerjee M, Sonnenday C, Morris AM. Surgical complications are associated with omission of chemotherapy for stage III colorectal cancer. Dis Colon Rectum 2010;53:1587-93.

2. Jones HJ, de Cossart L. Risk scoring in surgical patients. Br J Surg 1999;86:149-57. [CrossRef]

3. Copeland GP, Jones D, Walters M. POSSUM: a scoring system for surgical audit. Br J Surg 1991;78:355-60. [CrossRef]

4. Tekkis PP, McCulloch P, Poloniecki JD, Prytherch DR, Kessaris N, Steger AC. Risk-adjusted prediction of operative mortality in oesophagogastric surgery with O-POSSUM. Br J Surg 2004;91:288-95. [CrossRef]

5. Tekkis PP, Prytherch DR, Kocher HM, Senapati A, Poloniecki JD, Stamatakis JD, et al. Development of a dedicated risk-adjustment scoring system for colorectal surgery (colorectal POSSUM). Br J Surg 2004;91:1174-82. [CrossRef]

6. Leung E, McArdle K, Wong LS. Risk-adjusted scoring systems in colorectal surgery. Int J Surg 2011;9:130-5. [CrossRef]

7. Al-Homoud S, Purkayastha S, Aziz O, Smith JJ, Thompson MD, Darzi AW, et al. Evaluating operative risk in colorectal cancer surgery: ASA and POSSUM-based predictive models. Surg Oncol 2004;13:83-92. [CrossRef]

8. Park JE, Chung KS, Song JH, Kim SY, Kim EY, Jung JY, et al. The CReactive Protein/Albumin Ratio as a Predictor of Mortality in Critically Ill Patients. J Clin Med 2018;7:333. [CrossRef]

9. Nehring SM, Goyal A, Bansal P, Patel BC. C Reactive Protein (CRP). Treasure Island. FL: StatPearls; 2018.

10. Shalaby M, Di Lorenzo N, Franceschilli L, Perrone F, Angelucci GP, Quareisma S, et al. Outcome of Colorectal Surgery in Elderly Populations. Ann Coloproctol 2016;32:139-43. [CrossRef]

11. Prytherch DR, Whiteley MS, Higgins B, Weaver PC, Prout WG, Powell SJ. POSSUM and Portsmouth POSSUM for predicting mortality. Physiological and Operative Severity Score for the enUmeration of Mortality and morbidity. Br J Surg 1998;85:1217-20. [CrossRef]

12. Tekkis PP, Poloniecki JD, Thompson MR, Stamatakis JD. Operative mortality in colorectal cancer: prospective national study. BMJ 2003;327:1196-201. [CrossRef]

13. Oh TK, Ji E, Na HS, Min B, Jeon YT, Do SH, et al. C-Reactive Protein to Albumin Ratio Predicts 30-Day and 1-Year Mortality in Postoperative Patients after Admission to the Intensive Care Unit. J Clin Med 2018;7:39. [CrossRef]

14. Wang F, Li P, Li FS. Prognostic role of C-reactive protein to albumin ratio in colorectal cancer: A meta analysis. Medicine (Baltimore) 2019;98:e16064. [CrossRef]

15. Yan J, Wang YX, Li ZP. Predictive value of the POSSUM, p-POSSUM, cr-POSSUM, APACHE II and ACPGBI scoring systems in colorectal cancer resection. J Int Med Res 2011;39:1464-73. [CrossRef] 
ORİJINAL ÇALIŞMA - ÖZET

\section{Kolorektal kanserli hastalarda C-reaktif protein ve plazma albumin seviyesinin oranı mortalite ve morbiditeyi göstermede alternatif bir skorlama olabilir mi ?}

\section{Dr. Yeliz Şahiner, ${ }^{1}$ Dr. Murat Baki Yıldırım²}

${ }^{1}$ Hitit Üniversitesi Tıp Fakültesi, Anesteziyoloji ve Reanimasyon Anabilim Dalı, Çorum

${ }^{2}$ Hitit Üniversitesi Tıp Fakültesi, Genel Cerrahi Anabilim Dalı, Çoru

AMAÇ: Bu çalışmada, kolorektal kanser nedeniyle ameliyat edilen ve yoğun bakımda takip edilen hastalarda, C-reaktif proteinin plazma albüminine oranının (CRP/ALB), güncel skorlama sistemleri ile karşılaştırılarak, morbidite ve mortaliteyi ön görmedeki sensitivite ve spesifitesini ortaya koymak amaçlanmıştır.

GEREÇ VE YÖNTEM: Kliniğimizde 20I5-20I8 yılları arasında verilerine ulaşılabilen kolorektal kanser nedeniyle ameliyat olan ve yoğun bakımda yatan hastaların verileri geriye dönük incelendi. CRP/ALB, hem gastrointestinal hemde kolorektal cerrahi için hazırlanan, physiological and operative severity score for the enumeration of mortality and morbidity (POSSUM) ve kolorektal hastalar için hazırlanan "Association of Coloproctology of Great Britain and Ireland” (ACPGBI-CRC) skorlama sistemlerinin mortalite ve morbidite ön görmedeki başarıları karşılaştırıldı.

BULGULAR: Toplam I I 9 hasta çalışmada değerlendirilmeye alındı. Hastaların dokuzunda mortalite, 38'inde morbidite olduğu görüldü. Morbiditeyi gösteren tek skorlama sistemi olan P-POSSUM ile kıyaslandığında CRP/ALB oranının daha yüksek bir doğrulukla ön görüsü olduğu bulundu. Mortaliteyi göstermede, CRP/ALB değerinin P-POSSUM, CR-POSSUM ve ACPGBI-CRC'ye oranla daha zayıf olduğu tespit edildi.

TARTIŞMA: Skorlama sistemleri kolorektal hastalarda morbidite ve mortaliteyi tahmin etmede kullanışlı olsa dahi pratikte çok fazla parametre içerdikleri için kullanımları zordur. Bu çalışmanın sonuçlarına göre, ek maliyet getirmeden hesaplanabilecek CRP/ALB oranının mortalite ve özellikle morbiditeyi tahmin etmede klinisyene yardımcı olabileceğini düşünüyoruz.

Anahtar sözcükler: Kolorektal kanser; organ bozukluk skorlamaları; prognoz; ROC eğrisi; yaşlı; yoğun bakım.

Ulus Travma Acil Cerrahi Derg 2020;26(4):580-585 doi: 10.14744/tjtes.2020.344I2 